\section{Renewable Agriculture and \\ Food Systems}

\section{cambridge.org/raf}

\section{Themed Content: Ag/Food Systems and Climate Change}

*Previous address: Department of Geography, University of Western Ontario, London, Ontario, Canada

Cite this article: Bezner Kerr R, NyantakyiFrimpong H, Dakishoni L, Lupafya E, Shumba L, Luginaah I, Snapp SS (2018). Knowledge politics in participatory climate change adaptation research on agroecology in Malawi. Renewable Agriculture and Food Systems 33, 238-251. https://doi.org/10.1017/

S1742170518000017

Received: 15 July 2017

Accepted: 29 December 2017

\section{Key words:}

Agroecology; climate-change adaptation; coproduction of knowledge; gender; participatory research; political ecology

Author for correspondence:

Rachel Bezner Kerr, E-mail: rbeznerkerr@ cornell.edu

\title{
Knowledge politics in participatory climate change adaptation research on agroecology in Malawi
}

\section{Rachel Bezner Kerr ${ }^{1, \star}$, Hanson Nyantakyi-Frimpong ${ }^{2}$, Laifolo Dakishoni ${ }^{3}$, Esther Lupafya ${ }^{3}$, Lizzie Shumba ${ }^{3}$, Isaac Luginaah ${ }^{4}$ and Sieglinde S. Snapp ${ }^{5,6}$}

${ }^{1}$ Department of Development Sociology, Cornell University, 262 Warren Hall, Ithaca, NY 14853, USA; ${ }^{2}$ University of Michigan, School of Public Health (3846 SPH I), 1415 Washington Heights, Ann Arbor, MI 48109, USA; ${ }^{3}$ SFHC Organization, P.O. Box 36, Ekwendeni, Malawi; ${ }^{4}$ Department of Geography, University of Western Ontario, London, Ontario, Canada; ${ }^{5}$ Center for Global Change and Earth Observations, Michigan State University, East Lansing, MI, USA and ${ }^{6}$ Department of Plant, Soil and Microbial Sciences, Michigan State University, East Lansing, MI, USA

\begin{abstract}
Climate change is projected to have severe implications for smallholder agriculture in Africa, with increased temperatures, increased drought and flooding occurrence, and increased rainfall variability. Given these projections, there is a need to identify effective strategies to help rural communities adapt to climatic risks. Yet, relatively little research has examined the politics and social dynamics around knowledge and sources of information about climate-change adaptation with smallholder farming communities. This paper uses a political ecology approach to historically situate rural people's experiences with a changing climate. Using the concept of the co-production of knowledge, we examine how Malawian smallholder farmers learn, perceive, share and apply knowledge about a changing climate, and what sources they draw on for agroecological methods in this context. As well, we pay particular attention to agricultural knowledge flows within and between households. We ask two main questions: Whose knowledge counts in relation to climate-change adaptation? What are the political, social and environmental implications of these knowledge dynamics? We draw upon a long-term action research project on climate-change adaptation that involved focus groups, interviews, observations, surveys, and participatory agroecology experiments with 425 farmers. Our findings are consistent with other studies, which found that agricultural knowledge sources were shaped by gender and other social inequalities, with women more reliant on informal networks than men. Farmers initially ranked extension services as important sources of knowledge about farming and climate change. After farmers carried out participatory agroecological research, they ranked their own observation and informal farmer networks as more important sources of knowledge. Contradictory ideas about climate-change adaptation, linked to various positions of power, gaps of knowledge and social inequalities make it challenging for farmers to know how to act despite observing changes in rainfall. Participatory agroecological approaches influenced adaptation strategies used by smallholder farmers in Malawi, but most still maintained the dominant narrative about climate-change causes, which focused on local deforestation by rural communities. Smallholder farmers in Malawi are responsible for $<1 \%$ of global greenhouse gas emissions, yet our results show that the farmers often blame their own rural communities for changes in deforestation and rainfall patterns. Researchers need to consider differences knowledge and power between scientists and farmers and the contradictory narratives at work in communities to foster long-term change.
\end{abstract}

\section{Introduction}

Climate change poses a major challenge and threat to smallholder farmers in sub-Saharan Africa (SSA), largely reliant on rain-fed farming systems (Niang et al., 2014). Recent assessments indicate that in the coming years, SSA will experience more erratic rainfall patterns, increased peak and seasonal mean temperatures, higher frequency and intensity of droughts, as well as overall reduced crop yields (Niang et al., 2014). Already, many smallholder households in SSA experience chronic food insecurity and persistently high levels of poverty (Von Grebmer et al., 2015), which has been shaped by colonial and postcolonial policies that privileged certain groups, alongside conflicts and neoliberal policies which have exacerbated economic conditions (Bassett and Winter-Nelson, 2010). Climate change will likely exacerbate the already poor state of food security in the region.

Against this backdrop, there is a need to share current knowledge and identify effective strategies to help rural communities adapt to climatic risks. There is an extensive literature 
on the human dimensions of climate change, yet gaps remain (Davidson, 2016). In particular, relatively little research has examined the politics and social dynamics around knowledge and sources of information about climate-change adaptation in Africa. Overall, we ask:

1. Whose knowledge counts in relation to climate-change adaptation?

2. What are the political, social and environmental implications of these knowledge dynamics?

We answer these questions by drawing upon the literature on agroecology (e.g., Altieri et al., 2015; Snapp, 2017) and the co-production of knowledge (e.g., Fazey et al., 2010; Reyers et al., 2015), with a political ecology analytical framing sensitive to historical context (Taylor, 2015). Empirical findings are presented based on 4 years of participatory action research on climate-change adaptation in Malawi, southern Africa. Malawi offers a compelling case study, being one of the countries expected to be most affected by climate change, and one where rural smallholder households already struggle with poverty and food insecurity (FAO, 2014; Von Grebmer et al., 2015).

\section{Knowledge co-production, agroecology and climate-change adaptation}

Recent scholarship on the politics of climate-change adaptation draws attention to the political dimensions of adaptation strategies, social inequalities and contradictory outcomes (Ribot, 2014; Eriksen et al., 2015; Taylor, 2015). Vulnerability to climate change can be shaped by peoples' relative position in society and access to types of knowledge (Ribot, 2014; Eriksen et al., 2015). Dominant narratives and domains of authority can determine adaptive strategies in a given time and place (Eriksen et al., 2015; Taylor, 2015). Successful adaptive strategies are thought to lead to resilience, defined as an individual or community's capacity to recover from socio-ecological stresses (Folke, 2006). In this study we take a political ecology approach to resilience and adaptation, in that rather than trying to reproduce social relations and processes that might reinforce or worsen social inequalities, resilience produces new socio-ecological forms, ones that are more just and sustainable (Taylor, 2015). Social processes and relations that affect the potential for adaptation and resilience- including forms of extraction, exclusion and marginalization-are often deeply gendered alongside other forms of social inequality (i.e., class, ethnicity). Thus this study paid explicit attention to gender and other forms of vulnerability-in this case poverty, health status and age.

One area of contested knowledge of climate-change adaptation is that of appropriate agricultural strategies. Agroecology aligns with political ecology approaches to resilience. A set of farming practices as well as a broader social movement (Altieri et al., 2015), agroecology relies on in-depth knowledge of crop, insect and disease ecology, harnessing biological processes, and increased agrobiodiversity with attention to interactions with adjacent natural landscapes (Snapp, 2017). Agroecological approaches include attention to social, economic and political dynamics that shape food production, local knowledge and building farmer capacity to innovate as well as specific technical practices that draw on ecological principles (Altieri et al., 2015). Agroecological strategies show transformative potential to address resilience. Several studies on the impacts of different farming practices on the response to hurricanes and droughts found that agroecological methods helped farms withstand damage and recover faster (Altieri and Nicholls, 2017; Rogé et al., 2014). A study in Malawi found that more diverse farms that had several different crops in one field had improved soil quality, were better able to withstand the stress of higher temperatures under drought, and more stable yield over time (Snapp et al., 2010). Recent policy advocates call for more agroecological approaches to climate-change adaptation (De Schutter, 2013). While there is increasing political mobilization related to agroecology, there are few empirical studies that use agroecological methods, particularly in SSA and limited attention to the political and social dimensions of agroecological approaches (Bellamy Sanderson and Ioris, 2017).

Agroecological approaches rely upon building farmers' knowledge, observations and capacity to experiment and adjust practices to specific agroecosystems. This highlights the urgent need for rich and diverse sources of information in order to adapt both to the local environmental context and global climate change. Many scholars of agroecological approaches suggest drawing on indigenous knowledge is an essential part of agroecology (Altieri et al., 2015). Recognizing that there are many unequal power relationships inherent in scientific and indigenous communities, many researchers advocate for respectful collaboration that recognizes both the vulnerability of many rural communities to climate change, as well as the value of detailed observation and local experience (Altieri et al., 2015; Snapp, 2017). Increasing attention has been put towards a knowledge coproduction approach to manage social-ecological systems for climate change (Reyers et al., 2015), in ways that bring a plurality of knowledge together to understand it and address it in an integrated way (Armitage et al., 2011). Limited attention, however, has been given explicitly to social differentiation, including race, class and gender, within farming communities that can prevent access to knowledge for adaptation. Health status is another marker of social difference, and in the context of SSA, HIV affected households struggle with a range of inequalities, including loss of land, exclusion from community development activities, greater nutritional needs and often social stigma explicitly linked to HIV status (Bryceson and Fonseca, 2006; Nyantakyi-Frimpong et al., 2016). Such inequalities have direct impacts on HIV positive farmers' access to knowledge alongside other agricultural resources.

Knowledge production as such is both a political as well as a social act, and there has been increased interest in this messy world of negotiating meaning, addressing tacit knowledge, uncertainty, and acknowledging the limitations of scientific knowledge (Jasanoff, 2004; Rogers et al., 2013; Ribot, 2014). Jasanoff (2004) developed the concept of the co-production of knowledge, in that science and society are co-produced and reflect political power as well as technological progress. Coproduction of knowledge has been applied to socio-ecological systems and adaptation research (Armitage et al., 2011; Reyers et al., 2015). In the agricultural sciences, a drive towards simplification and standardization reflects political and economic hegemonic corporate and state interests (Weis, 2007), as well as a modernization paradigm that favors uniformity, rationality and order (Moseley et al., 2016). In Africa, this is an important context to consider, as the agricultural intensification narrative has become dominant in many agricultural programs and policies, which use modernization motifs and often draw on state power for implementation. Recent calls for a 'new' Green Revolution in Africa often emphasize chemical and purchased inputs, irrigation and linking farmers to external markets, reflecting this modernization imperative of the earlier Green Revolution with a new emphasis on genetically modified seeds 
and a more dominant role of corporate actors (Moseley et al., 2016). The agricultural intensification model is in stark contrast to resilience studies in climate-change adaptation which call for greater agrobiodiversity, flexible approaches that reflect local context, ability to learn from mistakes, working across scales and recognizing local knowledge (Altieri et al., 2015). Co-learning and integration of lay knowledge can support climate-change adaptation (e.g., Fazey et al., 2010). While these studies illustrate ways to integrate heterogeneous knowledge and how to address local unequal power dynamics, there are few studies that examine the broader context within which farmers are negotiating and engaged with co-learning for adaptation using agroecological methods. A political ecology approach to resilience using agroecology might ask who has access to agricultural knowledge? And what are the implications of an agroecological approach for political struggles and social inequalities, including gender, related to knowledge?

Gender implications have not been fully explored in terms of different approaches to knowledge production and sources of agricultural advice. It has been well documented that women are often excluded from extension support, and that often the wealthiest farmers are the greatest recipients of extension services (World Bank and IFPRI, 2010; cited in Croppenstedt et al., 2013). The net result of the gendered nature of agricultural science is that women farmers often lack substantial technical information that might assist them in farming, and their needs, preferences and concerns are systematically excluded from agricultural research priorities. This gender inequality has implications for women's labor and consequently limits their exposure to alternative agroecological methods to improve household food security. In the context of Malawi, gender inequality has had significant impacts on women's access to knowledge and other resources (Bezner Kerr, 2017).

\section{Malawi: The history of smallholder agriculture, extension services and knowledge diffusion}

Malawi has a current population of 16.4 million, over $80 \%$ of who live in rural areas and rely on agriculture for their food and livelihoods (FAO, 2014; World Bank, 2017). An estimated 70\% of the population lives below the poverty line, with higher rates in rural areas (World Bank, 2017). About one in three Malawian households experience chronic food insecurity and calorie deficiencies (FAO, 2014). The majority of arable land in Malawi is devoted to maize production, and almost half of the Malawian diet consists of maize. Gender inequality is another crucial determinant of food insecurity. Rural women in Malawi generally have unequal social status and roles, including high rates of domestic violence, limited control over resources and high workloads (NSO and ICF, 2017). Women are typically responsible for cooking, child care, food processing, fuelwood and water collection and caring for the ill, and these multiple roles, combined with limited control over decision-making leave women in a particularly vulnerable context in relation to climate change and food security (Bezner Kerr et al., 2016a). Another key marker of vulnerability and social inequality is HIV status: approximately $10 \%$ of adults in Malawi are HIV positive, with adolescent girls three times more likely to contract HIV than adolescent boys due to inadequate economic, social, educational and legal support (Underwood et al., 2011). HIV positive women are at greater risk of food insecurity, nutritional and health concerns, alongside social stigma (Bryceson and Fonseca, 2006). There is evidence that HIV positive women in Malawi experience higher rates of poverty, shift more of their labor to other income-generating activities and away from farming (Bignami-Van Assche et al., 2011).

A key feature of post-Independence Malawi has been increased alienation of customary land to the estate sector, as a means to support political allies and increase export tobacco production. At the same time the state agricultural system provided modest support to smallholders through extension, subsidized fertilizer, access to credit, rural depots and a national seed program, primarily focused on maize for maintaining food security and more often benefitting men (Ellis et al., 2003).

Structural adjustment in the 1980s, imposed by the IMF after Malawi faced a fiscal crisis, led to cutbacks in extension alongside the partial removal of subsidies, and fewer rural depots. Several multinational companies entered seed and fertilizer sales. The health system was also dramatically cut back, which had severe impacts on the HIV epidemic and AIDS-affected families. Under the first democratically elected President Muluzi in 1994, sharp devaluation and subsidy removal required by the IMF and World Bank led to the collapse of the agricultural credit system and combined with increased input costs, dramatic reductions in smallholder production (Peters, 2006). These broader political economic shifts transformed the country from being maize self-sufficient in non-drought years, to one highly dependent on donors and imported food aid. It was in this highly politicized and sensitive context that Bingu Wa Mthalika (re)introduced a larger agricultural input subsidy program, which provided about 1.5 million households with one $50 \mathrm{~kg}$ bag of subsidized fertilizer and hybrid maize seed (Chirwa and Dorward, 2013). The impact of this program is widely debated, as reported increases in maize production are contested (FAO, 2014; Messina et al., 2017), and food insecurity and undernutrition remain high (Chirwa and Dorward, 2013). Fertilizer subsidies, the involvement of private sector and government institutions have thus varied markedly over the last three decades. One inadvertent outcome of increased tobacco production (World Bank, 2017), alongside increased charcoal production, has been associated deforestation.

The standard model for agricultural education, beginning with the colonial state to the present, is that of the agricultural extension worker, who imparts expert knowledge to the farmer. National extension programs were significantly reduced during structural adjustment, with extension training programs shut down, transport and other incentives removed (CISANET, 2013). The Government implemented the National Extension Policy in 2000, which emphasized farmer demand, accountability, pluralism and coordination (Ragasa et al., 2015). Multinational seed companies such as Pioneer and Monsanto partnered with international non-governmental organizations and the government to promote different technologies, using agricultural extension agents. The 'Lead Farmer' approach initiated more recently still draws on this notion of expert knowledge, now deeply entwined with corporate sources of information and power (Chinsinga, 2011). The rise of the subsidy program, however, has overshadowed extension. A recent national survey found 40 percent of households reported extension services for maize were worse compared with 5 years earlier (Ragasa et al., 2015). National spending on public agricultural extension is estimated at $<2 \%$ of the total agricultural budget in 2013, declining from $19 \%$ in 2000 , as the subsidy program has dwarfed other costs in the Ministry of Agriculture's budget (Ragasa et al., 2015). Typical extension strategies continue to be very hierarchical, 
uneven, unresponsive to farmer needs and gendered (Chowa et al., 2013).

\section{The case study sites}

The study took place in two sites: Ekwendeni catchment area in Mzimba District in the Northern region, and Traditional Authority (TA) Simlemba in Kasungu District in the Central region (Fig. 1). Both sites are mid-altitude (1000-1200 $\mathrm{m}$ asl), sub-tropical ecosystems, with unimodal rainfall during the months of December-April (700-1300 $\mathrm{mm} \mathrm{yr}^{-1}$ ). The typical cropping pattern of smallholders in both sites has been maize
(Zea mays) as the dominant staple crop, other food crops grown at low density including finger millet (Eleusine coracana), sweet potatoes (Ipomoea batatas), groundnut (Arachis hypogaea) and tobacco (Nicotiana tabacum) for about one-quarter of the households. While tobacco is an important cash crop in both sites and in Malawi more broadly, an inadvertent outcome of increased tobacco production, alongside increased charcoal production, has been associated deforestation (Zulu, 2010). We chose these two research sites in part due to the evidence of frequent drought occurrences in these regions in the historical record, and the limited agricultural and social research in the north and central regions compared with the south. Another

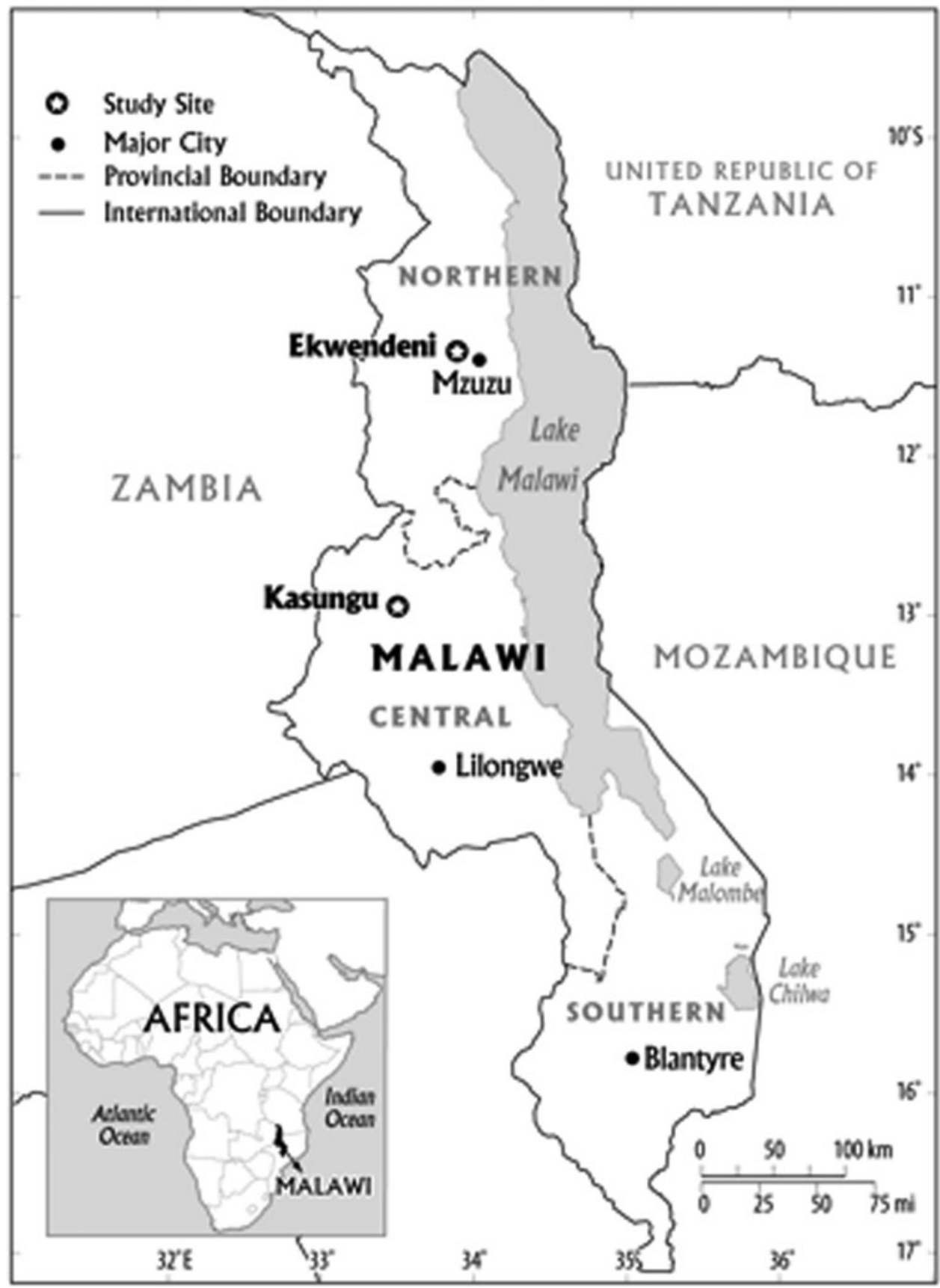

Prodoced by. The Cotograptic Section, Dese. of Geogragty, Westers, 2006. 137-06

Fig. 1. The study sites. Source: Map drawn by The Cartographic Section, Department of Geography, Western University. 
major reason for selection of these sites is a longer-term partnership with farmer groups.

\section{Research methods}

The overall project objective was to conduct participatory action research with farmers (of different ages, gender, food security status and HIV status) to assess different adaptation strategies for addressing climate change, health and food security. The research design was quasi-experimental, case-control, pre-post longitudinal trials in 31 villages by 425 farmers on different cropping, livestock, agroforestry and livelihood diversification strategies to improve food security and adaptation to climate change. Villages were selected through random sampling. Purposive, nonprobability sampling methods were then used to select participating households within villages. Farmers were selected by village members based on household food security (i.e., low), HIV status (if known) and age (to ensure inclusion of youth). There were several different sets of intervention activities (Table 1).

After training on agroecological principles, each household selected several strategies to test, including some of the following elements: (1) integration of trees (use of fruit trees and/or agroforestry); (2) soil fertility and/or conservation strategy; (3) crop diversification, including legume intercrops and (4) livelihood diversification, such as dry season gardens, small livestock and bee-keeping (Fig. 2). These strategies were generated through a co-production process, which involved a combination of scientific review, dialogue, input from farmers and joint decision-making by scientists and participating farmers. A list of potential strategies was drawn from a literature review on climate-change adaptation, and then augmented with ideas from villages during a series of community dialogues at the village level. Participating households reflected and consulted on possible experiments before meeting again with the project team in smaller groups for more detailed discussions, leading to a final list of preferred experiments. Participating households met monthly to discuss their experiments. In addition, the groups participated in different educational activities to raise awareness and discussions about sources of social inequality, such as gender and health status, and ways to reduce this inequality.

This longitudinal participatory research study involved multiple data collection procedures, including interviews, focus groups, a baseline survey, adaptation experiments, field visits and two surveys of households doing experiments (Table 2). Twenty-five in-depth interviews and six focus group discussions on farmer perceptions were conducted in 2009, and follow-up interviews with 25 participants and three focus groups were conducted in 2013. Interview participants were selected using purposive, nonprobability sampling methods based on variation in agroecosystems, food security, age, gender and health status. The focus groups were conducted at six different sites and involved 10-15 mixed groups of men and women. There were questions about rainfall patterns, experiences during periods of drought, and crops grown in the past. Both the interviews and focus groups took between one to one and a half hours. The interviews and focus groups were recorded, transcribed and translated. Research team members carried out field visits periodically and took field notes, which were considered part of the dataset. Qualitative analysis was completed by hand, with the first authors reading through the data and identifying key themes and contradictions, following Miles et al. (2014). The search for negative cases, or disconfirming evidence, is a way to validate data findings in qualitative findings and can be crucial for delving into the meanings of a given phenomenon (Antin et al., 2015). An initial coding system was developed using a priori concepts such as 'climate-change perceptions' and additional codes were added using emic concepts, that is those based on the participants' understanding (such as 'chatting' as a source of information). Preliminary findings were shared and discussed with participating farmers as a form of respondent validation.

A cross-sectional baseline survey was done in 2010 with 1213 randomly selected households. Trained enumerators asked respondents questions about perceptions of rainfall patterns, drought occurrence, flooding, temperature and responses to weather changes as well as demographic and farming information. This survey was used to compile climate-change perceptions, current farming practices and possible adaptation strategies. The dataset also includes quasi-experimental, case-control, pre-post longitudinal trials in 31 villages by 425 farmers on different agroecological strategies to improve food security and adaptation to climate change. A survey of all participating households was conducted in February 2011 and 2013 to assess changes in agricultural practices, food security, knowledge, dietary diversity and other social and environmental variables. Data was entered into STATA 11 and

Table 1. Project timeline and activities

\begin{tabular}{|c|c|}
\hline 2000-2008 & $\begin{array}{l}\text { Previous participatory research by the team on legume diversification. Used small group discussions to have dialogues about difficult, } \\
\text { complex household and community factors that affected food security and nutrition and limited use of legume diversification. Learned } \\
\text { about traditional knowledge related to agroecology, and particular social inequalities which shaped people's ability to use different } \\
\text { agricultural methods, including HIV positive people, highly food insecure and youth. The research team decided to focus on agroecological } \\
\text { methods and participatory action research, including attention to social inequalities }\end{array}$ \\
\hline 2009 & Focus group discussions and interviews on farming practices, social inequalities and experiences with droughts and changing rainfall patterns \\
\hline July 2010 & $\begin{array}{l}\text { Began participatory action research project. The overall objective was to conduct participatory action research with farmers (of different ages, } \\
\text { gender, food security status and HIV status) to assess different adaptation strategies for addressing climate change, health and food } \\
\text { security. Met with prospective villages that had been selected randomly, to discuss the possibility of the project. Carried out a baseline } \\
\text { survey on perceptions of climate change, farming practices and demographic information. }\end{array}$ \\
\hline 2011 & $\begin{array}{l}\text { Farmers began participatory action research on agroecological methods, including different cropping, livestock, agroforestry and livelihood } \\
\text { diversification strategies to improve food security and adaptation to climate change. Conducted baseline survey with all participating farm } \\
\text { households, and carried out in-depth interviews with farmers }\end{array}$ \\
\hline 2011-2014 & $\begin{array}{l}\text { Supported farmers doing experiments. Held monthly meetings to assess experiments and reflect on results; carried out annual participatory } \\
\text { workshops with farmers to share experiences and reflect on results. Conducted research activities, e.g. interviews, focus groups and surveys }\end{array}$ \\
\hline 2013 & Conducted interviews with 30 government, civil society and donor representatives on climate-change adaptation strategies \\
\hline 2014 & $\begin{array}{l}\text { Held policy workshop with government representatives, international and national organizations to discuss climate-change adaptation } \\
\text { strategies }\end{array}$ \\
\hline
\end{tabular}



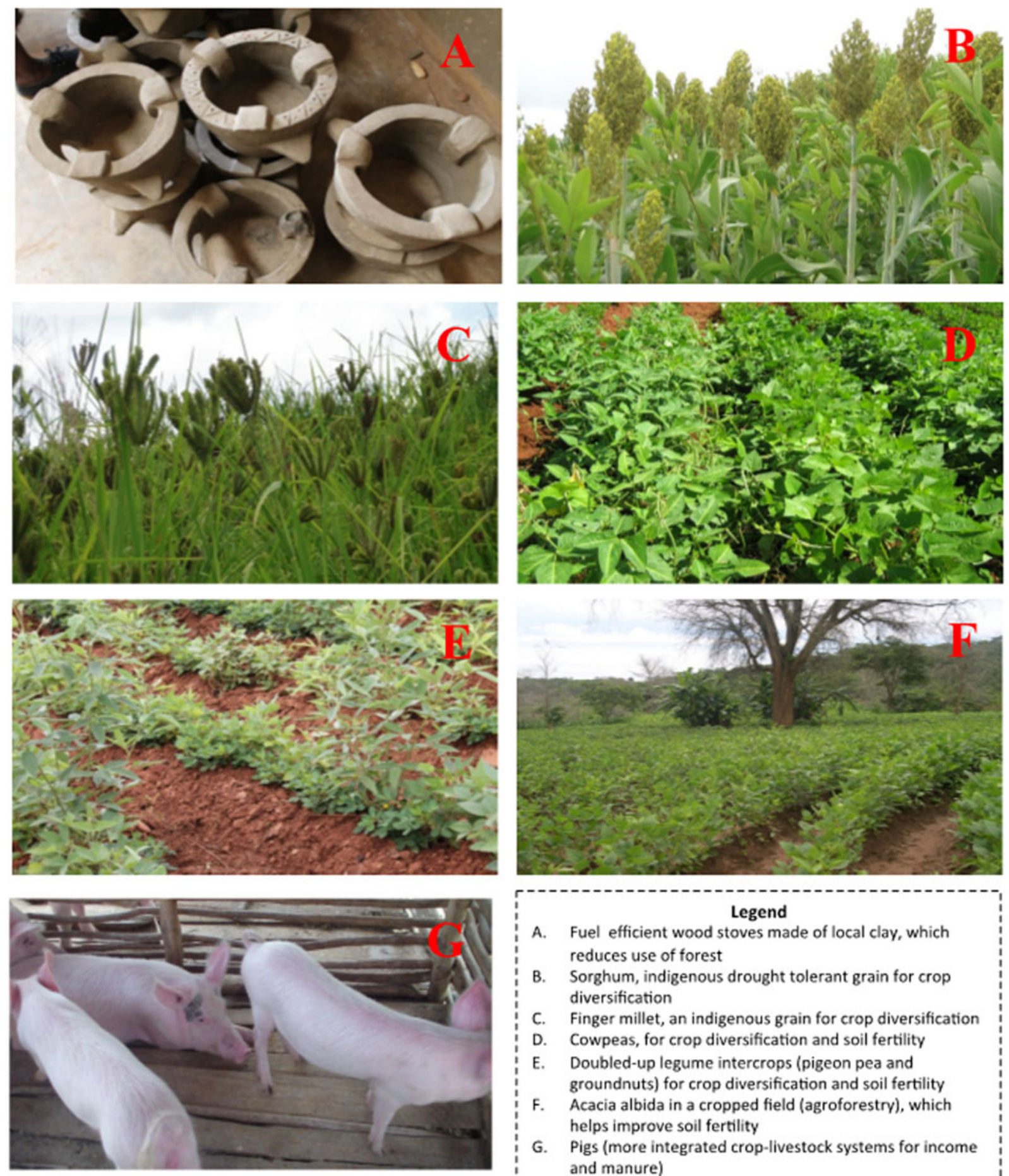

L. Fuel efficient wood stoves made of local clay, which
reduces use of forest
B. Sorghum, indigenous drought tolerant grain for crop
diversification
C. Finger millet, an indigenous grain for crop diversification
D. Cowpeas, for crop diversification and soil fertility
E. Doubled-up legume intercrops (pigeon pea and
Froundnuts) for crop diversification and soil fertility
G. Pigs (more integrated crop-livestock systems for income
and manure)

Fig. 2. Examples of agroecological practices tested by participating farmers.

descriptive analyses carried out. All tests of significance were calculated using $t$-tests for comparing two proportions.

In what follows, we focus on mixed methods data illustrating how farmers described their views about climate change, as well as the importance of agroecology as a climate-change adaptation strategy. We complement in-depth farmer accounts with descriptive findings from the surveys. It is important to acknowledge that in assessing local perceptions of climate change, a more rigorous approach would have been to compare local subjective views with the long-term meteorological data. However, we were unable to

access this long-term meteorological data in both the Mzimba and Kasungu districts in Malawi, a challenge highlighted by other researchers who have assessed climate-change perceptions in the country (Sutcliffe et al., 2016).

\section{Results}

The Results section has been organized into four sections. First, we describe the general characteristics of the sample. Next, we describe farmers' perceptions and ideas about climate change, 
Table 2. Overview of fieldwork methods and sampling

\begin{tabular}{|c|c|c|c|c|}
\hline Method & Themes covered & $\begin{array}{l}\text { Data acquisition } \\
\text { time }\end{array}$ & Sample size & Sampling approach \\
\hline In-depth interviews & $\begin{array}{l}\text { 1. Perceptions of climate change } \\
\text { 2. Existing adaptation strategies } \\
\text { 3. Crops grown in the past }\end{array}$ & 2009 and 2013 & 50 & Purposive sampling \\
\hline $\begin{array}{l}\text { Focus group discussions } \\
\text { (FGDs) }\end{array}$ & $\begin{array}{l}\text { 4. Local perceptions of climate change } \\
\text { 5. Main worries concerning agriculture } \\
6 \text {. Climatic and non-climatic stressors }\end{array}$ & 2009 and 2013 & $\begin{array}{l}\text { Nine FGDs, with } \sim 80 \\
\text { participants in total }\end{array}$ & Purposive sampling \\
\hline Survey & $\begin{array}{l}\text { 1. Socio-demographics } \\
\text { 2. Perceptions of rainfall patterns } \\
\text { 3. Drought occurrence } \\
\text { 4. Agricultural practices }\end{array}$ & 2010 & 1213 households & Random sampling \\
\hline
\end{tabular}

and how these perceptions differ by gender. The following sections describe sources of agricultural information, while the last section outlines changing dominant narratives on climate change.

\section{General household characteristics}

A total of 306 and 352 participating households were surveyed in 2011 and 2013, respectively. The general household characteristics are presented in Table 3. Almost a quarter of the respondents (24\%) were separated, divorced, widowed and living without a spouse. The survey respondents reported farming as the most common income source.

\section{Farmers' perceptions and ideas about climate change}

In 2009, focus group discussions and interviews, respondents consistently indicated that the start of planting rains began later in the season finished earlier. They also said that rains that used to come before the planting rains (and had a special name) no longer come or rarely occur. Older people indicated that it has been over a decade since these rains came. We verified this initial finding by asking young people if they remember these rains, and found consistently that they did not know or remember these rains. As one older woman noted during a focus group:

'The rains have changed a lot. Even after harvest the rains would come, called Chisindiranthamba [second rains]. Then one [rain] used to come in September, we would call it Chizimalupya (rain that put out the bush fires). After that there was Chikukulanyuni, that washed the ashes away. Then there was the planting rains. These early rains stopped in the late 1980s.' (Focus group 4, August 2009).

Some people also said that the rains are stopping in the middle of the rainy season more frequently, and are not as heavy at the beginning of the season as they used to be. The initial survey of over 1000 respondents in the area showed similar perceptions. The majority of respondents perceived a decline in the total amount of rainfall, a reduction or complete cessation of the early chizimalupya rains, and an earlier end to the rainy season. A higher percentage $(96 \%)$ of those who had lived in the area for longer than 10 years reported noticing that chizimalupya rains had changed over the years relative to both those who had lived in the area for a period of between 5-10 years (91\%) and $<5$ years $(88 \%)$. These differences were statistically significant.

During the focus groups in 2009, participants were also asked to indicate when droughts had occurred in their communities. We thought that the focus groups would be preferred for identification of drought years since participants could confirm and add to each other's memories of drought. Interestingly, there was considerable variation in the experience of drought throughout the 500 square kilometer region (Fig. 3). When describing severe droughts, people described patterns of migration, eating foods normally considered unacceptable, tremendous social upheaval and loss:

'Our parents suffered, they had to go to Nkhata Bay... where they took cassava.' (Focus Group 6 Aug 2009)

'1998-99 was the worst because people were just eating bananas and other unknown foods, many people died.' (Focus Group 1 Aug. 2009)

'2002 was the worst. We were eating maize husks.' (Focus Group 4 Aug. 2009)

These experiences suggest that at the time of the start of the research, many members of these rural communities lacked knowledge of alternative crops, forest foods, storage options, collective action and other options for households during drought. The lack of knowledge and preparation led to high costs for these households during previous droughts of recent memory, and there was room to build up social resilience and knowledge of different adaptation strategies prior to and during droughts.

In the follow-up survey in 2013 , about $50 \%$ of the respondents reported having experienced droughts in the past 3 years. Slightly less than half of the farmers (47\%) indicated that the climate is changing slowly, about one-third perceived rapid climate change, while $<1 \%$ of farmers indicated that the climate is not changing at all. These findings are similar to climate-change perceptions 
Table 3. General household characteristics

\begin{tabular}{|c|c|c|}
\hline Variable & $\begin{array}{l}\text { Baseline survey } \\
2011(n=306)\end{array}$ & $\begin{array}{c}\text { Final survey } \\
2013(n=352)\end{array}$ \\
\hline Average age & 47 years & 49 years \\
\hline Average household size & 5.6 & 5.9 \\
\hline \multicolumn{3}{|l|}{ Gender } \\
\hline Male & $38.85 \%$ & $41.15 \%$ \\
\hline Female & $60.7 \%$ & $57.4 \%$ \\
\hline \multicolumn{3}{|l|}{ Marital status } \\
\hline $\begin{array}{l}\text { Monogamous married and living } \\
\text { with spouse }\end{array}$ & $58.95 \%$ & $59.95 \%$ \\
\hline $\begin{array}{l}\text { Polygamous married and living } \\
\text { with spouse }\end{array}$ & $13.2 \%$ & $16.5 \%$ \\
\hline $\begin{array}{l}\text { Married and heading household; } \\
\text { spouse lives elsewhere }\end{array}$ & $0.95 \%$ & $3.1 \%$ \\
\hline $\begin{array}{l}\text { Separated/divorced/widowed, } \\
\text { living without spouse }\end{array}$ & $24.35 \%$ & $17.05 \%$ \\
\hline Never married & $1.75 \%$ & $0.85 \%$ \\
\hline \multicolumn{3}{|l|}{ Education } \\
\hline No schooling & $10.3 \%$ & $6.55 \%$ \\
\hline Some primary education & $57.85 \%$ & $57.35 \%$ \\
\hline Completed primary education & $17.4 \%$ & $22.45 \%$ \\
\hline Some secondary education & $10.45 \%$ & $8.5 \%$ \\
\hline Completed secondary education & $3 \%$ & $3.4 \%$ \\
\hline Post-secondary & $1.15 \%$ & $0.3 \%$ \\
\hline \multicolumn{3}{|l|}{ Sources of income } \\
\hline Farming & $59 \%$ & $70 \%$ \\
\hline Ganyu (casual labor) & $15 \%$ & $10 \%$ \\
\hline Selling farm produce & $16 \%$ & - \\
\hline Small business & $12 \%$ & $15 \%$ \\
\hline Sale of tobacco & $8 \%$ & - \\
\hline Sale of firewood & $2 \%$ & - \\
\hline Brewing beer & $2 \%$ & - \\
\hline
\end{tabular}

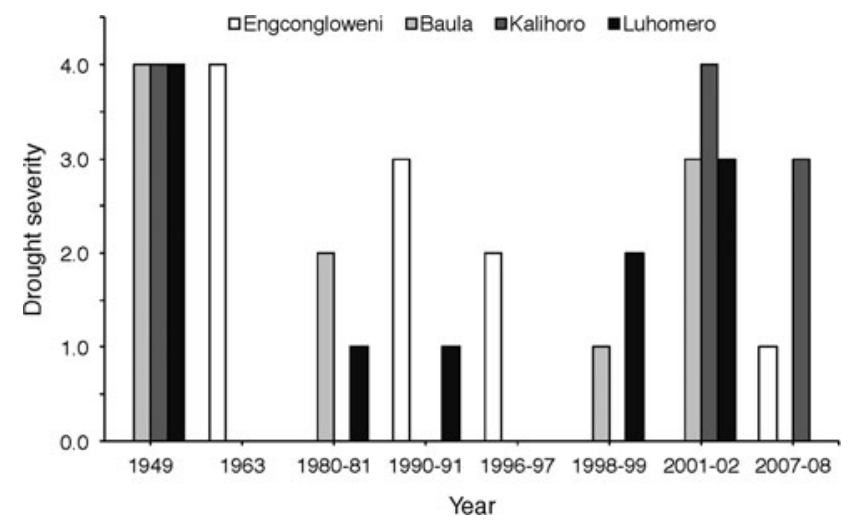

Fig. 3. Reported Occurrence of Droughts and Severity of Drought in northern Mzimba village areas. Note: one is least severe and four is the most severe. Data source: Focus Groups ( $n=6$ ), August 2009; ( $\sim 80$ people in four village areas). reported among smallholder farmers in other parts of southern Africa (Gbetibouo, 2009).

We also asked about people's views on the underlying causes of climate change. In the initial survey, deforestation was more commonly considered as the major cause of climate change compared with other perceived causes, mentioned by $46.4 \%$ of respondents compared to greenhouse gas emissions (2.6\%). However, there were significant differences between men and women, with more men (57.8\%) than women (39.5\%) attributing climate change to deforestation. Attribution of climate change to God's will was a more common response from those with primary or no formal education than from those with secondary or higher education in both men and women. These views were also more common among both women and men who had lived in the area for more than 10 years.

\section{Sources of agricultural information}

In the baseline survey in 2010, access to an agricultural extension was reported by $67 \%$ of respondents, with a statistically significantly higher percent of men (73\%) than women (63\%) stating that they had access to agriculture extension in the last 5 years (Fig. 4). In the 2011 survey with participating farmers, people were asked their top two sources of information, which they used in their farming, and the majority listed extension agents followed by farmer groups (Fig. 5), despite only 37\% reporting being visited by extension agents the previous year, and even fewer of those who were women farmers.

Another way to study flows of information was to ask whether people 'chatted' informally with others about farming. Most respondents $(79 \%)$ chatted informally and (75\%) said that they used information from their chatting in their farming, sometimes or often. The majority of people chatted with a neighbor or friend most often, followed by village leaders and then family members. These sources of informal knowledge sharing were also gendered: men were more likely than women to chat with village leaders and extension agents (Fig. 6). Interestingly, husbands and wives were not chatting with one another: in the northern site, $92 \%$ of farmers did not discuss farming with their spouse, while $75 \%$ did not chat with their spouse in the central site. Farmers chatted with other members of farmers' groups in $35 \%$ of households in the north, and $12 \%$ in the central site. These different gendered sources of agricultural information and flows of knowledge point to potential relations of exclusion from key adaptation

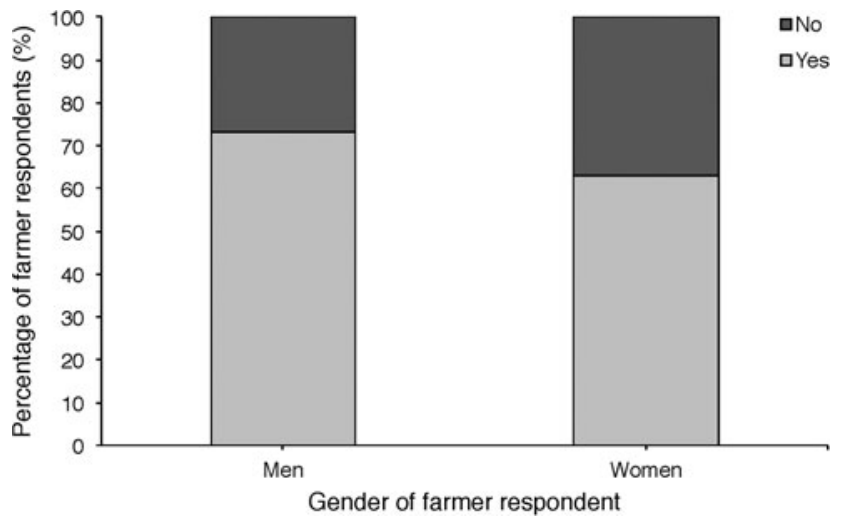

Fig. 4. Access to agricultural extension services by gender, baseline survey $(n=733)$ Access to agricultural extension varied significantly by gender using Chi-Square tests, $P$ value $=0.005$. 
Fig. 5. Reported source of informal sharing about farming information for both sites, and whether the respondent ever used the information (2011 and 2013 surveys). Data source: 2011 survey of participating smallholder farmers ( $n=292$ respondents) and 2013 survey $(n=302$ respondents) in Kasungu and Ekwendeni.

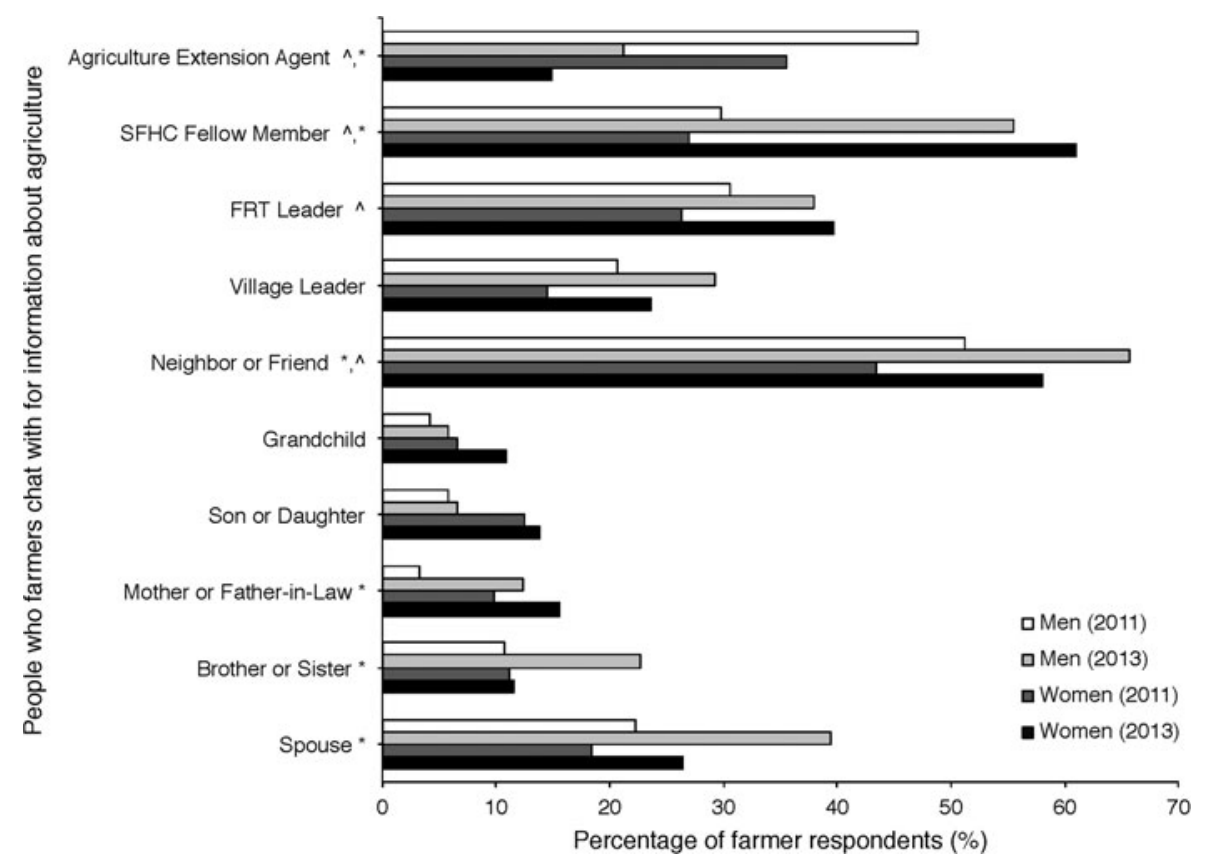

strategies. Unequal access to extension services and farmer groups might reinforce unequal gender differences in key resources, such as seeds, fertilizer and other technical inputs that extension workers, farmer groups and other groups (e.g. NGOs, seed companies) may provide access to, through these previously established social networks and information flows.

Beginning in 2011, the 425 farmer participants began experimenting with different agroecological practices of their choice, using a farmer participatory research approach and farmer-to-farmer teaching. Farming households also participated in village groups to share ideas, had farmer exchanges, and had training on various topics, including climate change. As part of the project, there was an emphasis on gender equity and social inclusion more broadly in training and activities.

After 2 years, there was a significant increase in food security and dietary diversity, with many farmers reporting using a range of agroecological practices including crop diversification, incorporation of organic material into the soil, and agroforestry (Bezner

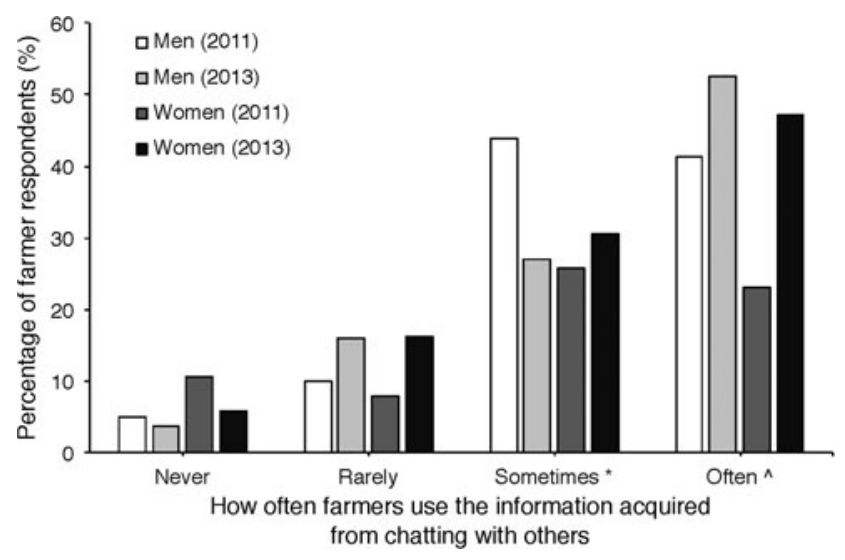

Fig. 6. Reported frequency of use of information acquired through informal 'chatting' with others about farming. ( $\%$ change is statistically significant for men, $P$ value $<0.05$; $\wedge \%$ change is statistically significant for women, $P$ value $<0.05$.) Data source: 2011 survey of participating smallholder farmers ( $n=292$ respondents) and 2013 survey ( $n=302$ respondents) in Kasungu and Ekwendeni.
Kerr et al., 2016b). When asked what was the most important way they learned farming information, agricultural extension agents were named as the most important source in $<10 \%$ of households, a significant change in 2 years (Fig. 5). The knowledge sources also appeared to change, with more people reporting chatting with their spouse or a participating farmer, and fewer people chatting with the extension agent (Figs. 6 and 7).

Learning about agroecological practices using participatory research methods empowered farmers to experiment with different practices which they thought might increase their resilience. In interviews and meetings, they spoke articulately about the ways in which soil moisture was better retained when organic matter such as crop residues was added, helping the crop to grow better and survive dry spells. They also described having a reduced risk of food insecurity from growing a greater diversity of crops and sharing this information with neighboring villages (Box 1).

Both men and women participated in these practices and expressed these ideas. The increased emphasis on farmer knowledge sharing and on gender equity seemed to have some effect on increased sharing between spouses (Figs. 6 and 7). There was also the perception that more vulnerable households, particularly those who had an HIV positive member, were more readily included in community activities because they had been explicitly included in the 'climate-change experiments'. There was a willingness to help these households by other farmers, and a sense of hope that if these households could improve their situation, then others could too. Several respondents indicated that this shift in thinking about the possibilities for change led to greater community collaboration (Project data, unpublished field notes). HIV positive respondents indicated that the project approach provided considerable support for their specific circumstances (Nyantakyi-Frimpong et al., 2016). In this sense the project's initiatives to address structural inequalities related to gender and health status through awareness raising and explicit access to inputs and information for these groups had significant impacts on their potential to use adaptation strategies-in keeping with Taylor's (2015) call to 'produce ourselves differently' for truly transformative climate-change adaptation efforts. 


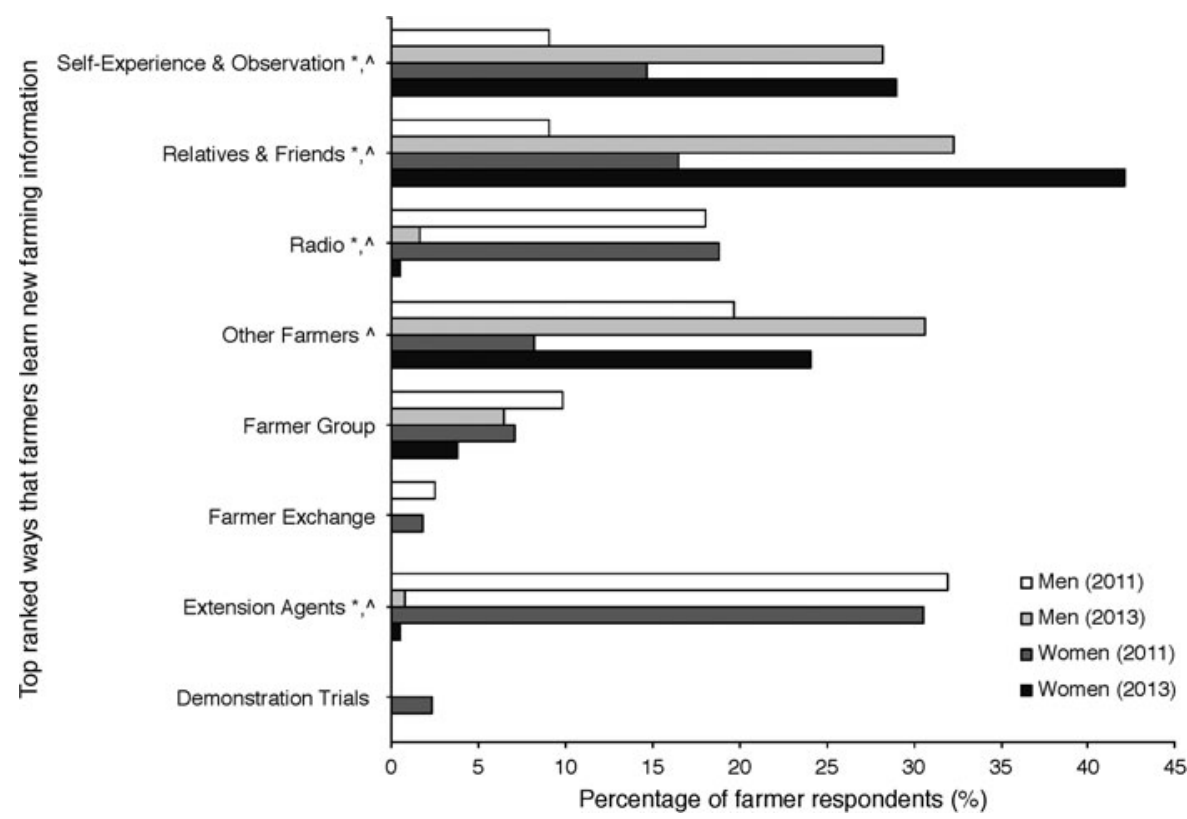

Fig. 7. Most important way farmers reported learning new farming information (farmers ranked the two most important sources of information) 2011 \& 2013 surveys. ( $\%$ change is statistically significant for men, $P$ value $<0.05 ; \wedge \%$ change is statistically significant for women, $P$ value $<0.05$.). Data source: Sources of agricultural information based on a 2011 survey of smallholder farmers ( $n=292$ respondents) and 2013 survey $(n=302$ respondents) in Kasungu and Ekwendeni. The agricultural field assistants and demonstration trials are part of Malawi government extension.
BOX 1 Case study village C.

- 'We have been growing soya and this had helped the children to be healthier than they were. We also planted many different types of trees to help improve the soil. Many of us also added pig manure to the soil which helped.' (male farmer 1 ).

- 'We started growing cassava, which we use for food, we eat both the tubers and the leaves.' (male farmer 2).

- 'We improved the soils. I noticed that where I grew soya and buried the residue, l've noticed a change in how the maize was doing. After germination, we would have to apply fertilizer. Now it grows without applying, and we're getting bigger yields.' (woman farmer 1).

- We've learned to grow finger millet. This season I've grown finger millet and now I grow the millet in ridges, instead of broadcasting it after cutting down the forest, which we used to do. Now I am getting bigger yields (male farmer 3).

- The times are changing and the rains are unpredictable, and it is good to have many crops in case maize fails... We are experimenting, and we're teaching what we've learned to others. We learned from fellow farmers in another village who are also in the project' (male farmer 1).

- The group met regularly, and met with four nearby villages to share seed and knowledge about how to grow finger millet without cutting down forested areas: 'When we harvested, we sat down and asked other village headmen, who in your village would be serious about using this seed? The headmen gave names, 10 per village, in four villages, and we told those people, 'you have to be serious about this so you can pay back the seed and continue helping other people...When we did this we talked to the whole village about climate change and our methodsand then we asked the village headmen for the names of serious people. Then, we gave seed and taught those people.' (Village headman, village $\mathrm{C}$ ).

Source: Author field notes, June 25, 2013

\section{Changing dominant narratives on climate change}

At the start of this research project, the authors observed very little discussion by the government about climate change. ${ }^{1}$ Throughout the study, the Government of Malawi increased discussion about climate change and the need for adaptation, likely in part due to increased donor interest due to the heavy reliance of the government on an international support (Gabay, 2015). The government's focus, however, was to increase monitoring of rural dwellers who used the forest for charcoal, fuelwood and other forest products. There was increased policing of forest areas and an increase in discussion of deforestation at the national level. The government also began promoting 'drought-tolerant' crops, mainly different hybrid varieties of maize, as a form of climate-change adaptation (Fig. 8). There was little discussion of other causes of climate change, such as the use of cars, electricity, nor was there acknowledgement of the rampant deforestation of state forests and sale abroad, a practice which had dramatically increased under the government of Bingu Mthalika, or the increased deforestation for agricultural production due in part to the fertilizer subsidy (Zulu, 2010).

At the end of the study we examined perceptions of climate change, and found that, while there was an increase in the proportion of people naming greenhouse gases as the major cause of climate change (to $10 \%$ of households), the majority of people continued to name deforestation as the primary cause, with tobacco production and related cutting of trees to cure tobacco the second most common, and God's will the third most common reason listed. A greater percentage of male respondents attributed climate change to deforestation compared with female respondents (Table 4). In addition, a significant proportion of male respondents (33\%) compared to female respondents (17\%) named tobacco production as the underlying cause of climate change.

During in-depth interviews with farmers in 2013, we asked their views about the underlying causes of climate change and

${ }^{1}$ Informal observation based on television and radio speeches of the government. Several of the authors reside permanently in Malawi. 


\section{Drought resistant maize variety unveiled 10 tonnes donated to subsidy}

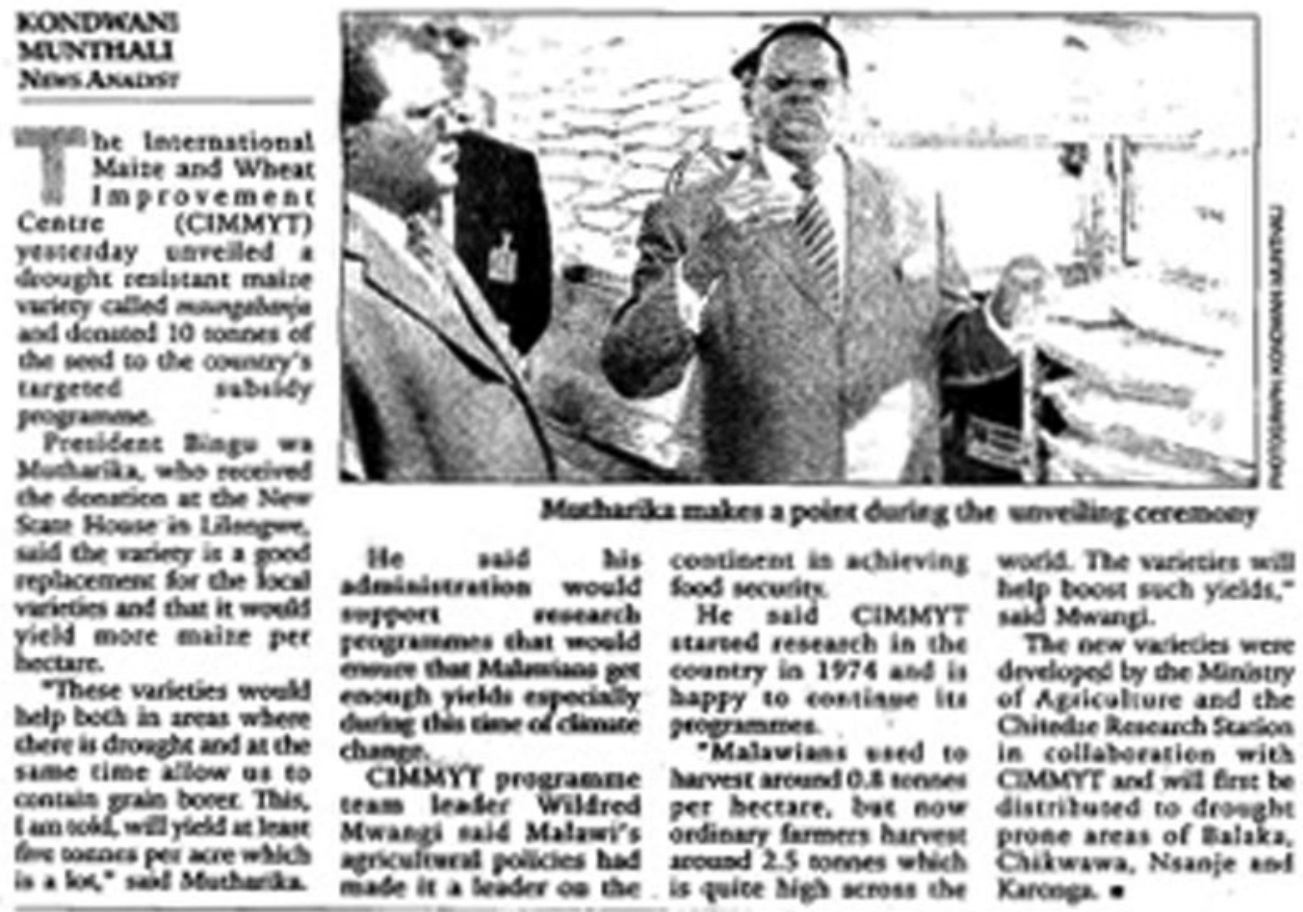

Fig. 8. Government promotion of drought-resistant, hybrid maize varieties as a form of climate-change adaptation. Source: Malawi Nation Newspaper.

compared these responses with findings from our survey. Almost all the interview respondents attributed climate change to deforestation, the cutting down of trees and overpopulation, often intertwining their responses:

People have been making a lot of charcoal in their area and a lot of trees have been cut. I think that's why climate has changed. [Martha, Female, married, Age 28-Interviewed July 29, 2013].

The mere finishing of natural trees which were in abundance in the past is the causes of climate change. [Stafel, Female, Divorced, Age 38-Interviewed July 31,2013$]$.

We think that because we have carelessly cut down the trees then the result is no rains. Overpopulation leading to bare lands due to wanton cutting down of tress. Strong winds which remove clouds that would bring rains. [Focus Group Discussion, Village B-July 30, 2013].

\section{Discussion and conclusion}

This study is one of the few participatory action research studies using agroecological approaches for climate-change adaptation, and the only one at the time of writing which explicitly focused on working with highly vulnerable groups as co-researchers in SSA, addressing a significant research gap (Bellamy Sanderson and Ioris, 2017). The study found that rural communities in Malawi perceived significant changes in climate, and that participatory research with marginalized groups using agroecology supported experimentation, increase knowledge sharing and flows, and challenged dominant agricultural models. Broader structural changes which address class and regional inequalities, however, and which challenge the dominant narrative about climate change were left unaddressed. Marked differences were found in local experiences with drought and rainfall pattern variability, which taken together highlighted the extreme variability of rainfall that is occurring over space and time. Older community members with long-term perspectives provided unique insights into changes in weather patterns, including the cessation of early rainfall that once broke the long dry spell between the planting rains, including the Chisindiranthamba, Chizimalupya and Chikukulanyuni rains. Overall, smallholder farmers were not only aware of changing rainfall patterns, they were very willing to invest in experimentation and in developing agricultural 
Table 4. Gender-disaggregated perceptions about the underlying causes of climate change, 2013 survey

\begin{tabular}{lcc}
\hline $\begin{array}{l}\text { Question: What do you think are the } \\
\text { causes of climate change? (Record } \\
\text { all that is mentioned) }\end{array}$ & $\begin{array}{c}\text { \% of Men } \\
\text { respondents }\end{array}$ & $\begin{array}{l}\% \text { of Women } \\
\text { respondents }\end{array}$ \\
\hline Transgression of cultural values & 0.7 & 0.5 \\
\hline Deforestation & 90 & 76 \\
\hline God's will & 10 & 16 \\
\hline Greenhouse gas emissions & 10 & 9 \\
\hline Overpopulation & 34 & 22 \\
\hline Tobacco production & 33 & 17 \\
\hline
\end{tabular}

${ }^{\text {a } T h i s ~ q u e s t i o n ~ f o l l o w e d ~ s e v e r a l ~ q u e s t i o n s ~ a b o u t ~ t h e ~ r e s p o n d e n t ' s ~ p e r c e p t i o n ~ o f ~ c h a n g e s ~ i n ~}$ temperature, rainfall patterns, droughts and flooding.

practices to adapt to these changes. Community perceptions related to causes of greenhouse gas emission and climate change were also assessed, and found to be dominated by concerns with local deforestation. Such perspectives were gendered and not markedly altered through trainings and interactions with the project. Dominant narratives about deforestation overrode local participatory training on climate change, supporting concerns about the limits of participatory climate-change adaptation research (Eriksen et al., 2015) and the challenges of co-produced knowledge (Ribot, 2014) in this political context.

Agricultural information was unequally shared through extension, with only one-third of people reporting being visited by an extension agent over the course of one year. At the same time, agricultural knowledge flows were also gendered-both in terms of extension agents, and along informal chatting, with the majority of people not discussing farming with their spouse. The main source of information about farming continues to be informal discussions with neighbors, friends and farmer groups.

In this context, there is evidence that a participatory action research project had some influence on the sources of information that people relied on for farming. The agroecological information provided and encouragement of farmer experimentation appeared to increase farmer confidence in their own observational skills and other farmers as important sources of agricultural knowledge. There is also evidence of increased collaboration within and between communities, including between spouses and those often excluded, such as AIDS-affected households. These findings point to the transformative potential of agroecology to a more sustainable food system when combined with participatory methods and attention to social inequalities (Bellamy Sanderson and Ioris, 2017). After 2 years, key sources of information about farming changed from extension services and radio, to farmer experimentation and informal networks. Co-production of knowledge using participatory methods, combined with agroecological approaches that used readily available resources, may have led farmers to trust their own experimentation and informal networks more in relation to climate-change adaptation (Arbuckle et al., 2015). In addition, the inconsistent and unreliable nature of extension services due to the broader political economic context (Chowa et al., 2013) made informal networks more available and reliable, as evidenced by increased use and valuing of informal knowledge sources when greater support was provided.

In contrast to this increase in equity and knowledge flows as a result of the participatory approaches taken, a more chilling response, a sentiment heard many times in the final year of the project, was that if they planted trees, the rains would come back, since deforestation was the cause of climate change. Smallholder farmers, who in Malawi would be responsible for $<1 \%$ of global greenhouse gas emissions, are blaming themselves and their rural communities for the dramatic changes in rainfall patterns, which they have observed over a generation. To be sure, there is some evidence that reforestation could change regional hydrological cycles (Moore et al., 2012) but a wholesale change in rainfall patterns without significant global reductions in greenhouse gas emissions cannot be expected, based on current scientific knowledge of global climatechange patterns. Knowledge about climate change and farming here was a combination of their own experience, (observed deforestation, increased tobacco production and charcoal making), our scientific intervention (discussion of agroecological approaches, explanations about climate change) and hegemonic narratives, which blamed the farmers themselves for the dramatic changes in rainfall patterns. These dominant narratives of blaming African farmers for land degradation have a long history in Malawi, and contemporary climate-change narratives appear to build on earlier, colonial and post-colonial notions of destructive farmers (Mulwafu, 2011) that benefit politicians and the timber industry while punishing rural communities. Thus our co-produced knowledge, while spurring change in farming practice, also reinforced unequal power dynamics in unexpected ways, as critical scholars of climatechange adaptation have noted in other sites (Taylor, 2015).

Thus, while a participatory research model using agroecology can support experimentation with farming practices and increase knowledge sharing and flows, thereby challenging dominant agricultural models, changing the dominant narrative about climate change is a greater challenge. This realization amongst the research team has led to new efforts, both to develop effective ways to share current knowledge on climate change, that translates across cultural, gender and income divides, and to discuss more often and openly about broader political economy dynamics which themselves are implicated in climate change. At the time of writing this paper, we have developed and tested a new curriculum that integrates agroecology, nutrition, social equity and climate change, written in collaboration with smallholder farmers (Bezner Kerr et al., under review).

Several scholars have written about the importance of being attentive to gender differences in vulnerability and to avoid falling into problematic assumptions about the priorities and experiences of rural poor households (Eriksen et al., 2015; Taylor, 2015). In this paper, we explored the ways in which knowledge was co-produced in scientific and hegemonic discourses, that at times reinforced power inequalities, while also empowering people to take action. Being attentive to the ways in which scientific and societal discourses are intertwining and interpreted is important if transformative change is to occur.

Acknowledgements. The involvement of Bunda College of Agriculture (now LUANAR)-in particular, Dr. George Kanyama-Phiri and Dr. Patson Nalivata as well as Patrick Thawe and Brian Kunkwenzu of MALEZA-in project implementation, is gratefully acknowledged. We acknowledge the many farmers who participated in the research. Additional helpful feedback was provided by Dr. Raj Patel. We also thank Jeff Liebert for the figures.

Funding. This work was funded by the Social Sciences and Humanities Research Council of Canada (\#410-2009-1434), the International Development Research Centre, Canada (grant \# 105152). SFHC was also supported by the Canadian FoodGrains Bank and Presbyterian World Service and Development during this research study. 


\section{References}

Altieri MA and Nicholls CI (2017) The adaptation and mitigation potential of traditional agriculture in a changing climate. Climatic Change 140(1), 33-45.

Altieri MA, Nicholls CI, Henao A and Lana MA (2015) Agroecology and the design of climate change-resilient farming systems. Agronomy for Sustainable Development 35(3), 869-890.

Antin TMJ, Constantine NA and Hunt G (2015) Conflicting discourses in qualitative research: the search for divergent data within cases. Field Methods 27(3), 211-222. doi: 10.1177/1525822X14549926.

Arbuckle JG Jr., Morton LW and Hobbs J (2015) Understanding farmer perspectives on climate change adaptation and mitigation: the roles of trust in sources of climate information, climate change beliefs, and perceived risk. Environment and Behavior 47(2), 205-234.

Armitage D, Berkes F, Dale A, Kocho-Schellenberg E and Patton E (2011) Co-management and the co-production of knowledge: learning to adapt in Canada's Arctic. Global Environmental Change 21(3), 995-1004.

Bassett T and Winter-Nelson A (2010) The Atlas of World Hunger Chicago: University of Chicago Press.

Bezner Kerr R (2017) Gender and Agrarian inequalities: from global systems to household relations. In Snapp SS and Pound B (eds). Agricultural Systems: Agroecology and Rural Development, 2nd edn. Boston, MA: Elsevier, pp. 333-370.

Bezner Kerr R, Chilanga E, Nyantakyi-Frimpong H, Luginaah I and Lupafya E (2016a) Integrated agriculture programs to address malnutrition in northern Malawi. BMC Public Health 16(1), 1197.

Bezner Kerr R, Nyantakyi-Frimpong H, Lupafya E, Dakishoni L, Shumba L and Luginaah I (2016b) Building resilience in African smallholder farming communities through farmer-led agroecological methods. In Sekhar Nagothu U (ed.). Climate Change and Agricultural Development: Improving Resilience through Climate Smart Agriculture, Agroecology and Conservation. London, UK: Routledge, pp. 109-130.

Bignami-Van Assche S, Van Assche A, Anglewicz P, Fleming $P$ and van de Ruit C (2011) HIV/AIDS and time allocation in rural Malawi. Demographic Research 24, 671-708. doi: 10.4054/DemRes.2011.24.27.

Bryceson DF and Fonseca J (2006) Risking death for survival: peasant responses to hunger and HIV/AIDS in Malawi. World Development 34 (8), 1654-1666.

Chinsinga B (2011) Seeds and subsidies: the political economy of input programmes in Malawi. Future Agricultures Working Paper, 13. Available at www.future-agricultures.org (last accessed 30 May 2017).

Chirwa E and Dorward A (2013) Agricultural Input Subsidies: The Recent Malawi Experience. Oxford, UK: Oxford University Press.

Chowa C, Garforth C and Cardey S (2013) Farmer experience of pluralistic agricultural extension, Malawi. Journal of Agricultural Education and Extension 19(2), 147-166.

Civil Society in Agriculture Network (CISANET) (2013) Policy Briefing: The State of Agricultural Extension Services in Malawi. Unpublished document.

Croppenstedt A, Goldstein M and Rosas N (2013) Gender and agriculture: inefficiencies, segregation and low productivity traps. The World Bank Research Observer 28, 79-109. doi: 10.1093/wbro/lks024.

Davidson D (2016) Gaps in agricultural climate adaptation research. Nature Climate Change 6(5), 433-435.

De Schutter O (2013) Report on the Special Rapporteur on the Right to Food, Mission to Malawi. New York, NY: United Nations. Available at http://www. srfood.org/images stories/pdf/officialreports/20140310_Malawi_en.pdf.

Ellis F, Kutengule M and Nyasulu A (2003) Livelihoods and rural poverty reduction in Malawi. World Development 31(9), 1495-1510.

Eriksen SH, Nightingale AJ and Eakin $\mathbf{H}$ (2015) Reframing adaptation: the political nature of climate change adaptation. Global Environmental Change 35, 523-533.

Fazey I, Kesby M, Evely A, Latham I, Wagatora D, Hagasua J-E, Reed MS and Chrisitie M (2010) A three-tiered approach to participatory vulnerability assessment in the Solomon Islands. Global Environmental Change 20, 713-728.

Folke C (2006) Resilience: the emergence of a perspective for social-ecological analyses. Global Environmental Change 16, 253-267.
Food and Agricultural Organization (FAO) (2014) Africa Food and Agriculture: FAO Statistical Yearbook 2014. Accra, Ghana: FAO and United Nations Regional Office for Africa.

Gabay C (2015) Exploring an African Civil Society: Development and Democracy in Malawi, 1994-2014. Lanham, Maryland: Lexington Books.

Gbetibouo GA (2009) Understanding Farmers' Perceptions and Adaptations to Climate Change and Variability: The Case of the Limpopo Basin, South Africa. Washington, DC: International Food Policy Research Institute.

Jasanoff S (ed.) (2004) States of Knowledge: The Co-Production of Science and the Social Order. New York, NY: Routledge.

Messina JP, Peter B and Snapp SS (2017) Re-evaluating the Malawian Farm Input Subsidy Programme. Nature Plants 3, 17013.

Miles MB, Huberman M and Saldana J (2014) Qualitative Data Analysis: A Methods Sourcebook. Thousand Oaks, CA: SAGE.

Moore N, Alagarswamy G, Pijanowski B, Thornton P, Lofgren B, Olson J, Anderson J, Yanda P and Qi J (2012) East African food security as influenced by future climate change and land use change at local to regional scales. Climatic Change 110(3-4), 823-844.

Moseley WG, Schnurr M and Bezner Kerr R (2016) Africa's Green Revolution: Critical Perspectives on New Agricultural Technologies and Systems. Oxford, UK: Taylor and Francis.

Mulwafu WO (2011) Conservation Song: A History of Peasant-State Relations and the Environment in Malawi, 1860-2000. Cambridge, UK: White Horse Press.

National Statistical Office (NSO) [Malawi] and ICF (2017) 2015-16 Malawi Demographic and Health Survey Key Findings. Zomba, Malawi, and Rockville, MD: NSO and ICF.

Niang I, Ruppel OC, Abdrabo EA, Lennard C, Padgham J, Urguhart P, Dube P and Leary N (2014) Africa. In Climate Change 2014: Impacts, Adaptation, and Vulnerability. Contribution of Working Group II to the Fifth Assessment Report of the Intergovernmental Panel on Climate Change. Cambridge, UK and New York, NY: Cambridge University Press, pp. 1199-1265.

Nyantakyi-Frimpong H, Mambulu FN, Bezner Kerr R, Luginaah I and Lupafya E (2016) Agroecology and sustainable food systems: participatory research to improve food security among HIV-affected households in northern Malawi. Social Science and Medicine 164, 89-99.

Peters P (2006) Rural income and poverty in a time of radical change in Malawi. Journal of Development Studies 42(2), 322-345.

Ragasa C, Mazunda J and Kadzamira M (2015) The Impact of Agricultural Extension Services within the Context of Heavily-subsidized Input System: The Case in Malawi, Draft IFPRI Discussion Paper. Washington, DC: IFPRI.

Reyers B, Nel JL, O'Farrell PJ, Sitas N and Nel DC (2015) Navigating complexity through knowledge coproduction: mainstreaming ecosystem services into disaster risk reduction. Proceedings of the National Academy of Sciences 112(24), 7362-7368. doi: 10.1073/pnas.1414374112.

Ribot J (2014) Cause and response: vulnerability and climate in the Anthropocene. Journal of Peasant Studies 41(5), 667-705.

Rogé P, Friedman AR, Astier M and Altieri MA (2014) Farmer strategies for dealing with climatic variability: a case study from the Mixteca Alta region of Oaxaca, Mexico. Agroecology and Sustainable Food Systems 38(7), 786-811. doi: 10.1080/21683565.2014.900842.

Rogers KH, Luton R, Biggs H, Biggs R, Blignaut S, Choles AG, Palmer CG and Tangwe $\mathbf{P}$ (2013) Fostering complexity thinking in action research for change in social-ecological systems. Ecology and Society 18(2), 31.

Sanderson Bellamy A and Ioris A (2017) Addressing the knowledge gaps in agroecology and identifying guiding principles for transforming conventional agri-food systems. Sustainability 9(3), 330. doi: 10.3390/su9030330.

Snapp SS (2017) Agroecology: principles and practice. In Snapp SS and Pound B (eds). Agricultural Systems: Agroecology and Rural Innovation for Development, 2nd edn. Academic Press, Elsevier, pp. 53-67.

Snapp SS, Blackie MJ, Gilbert RA, Bezner Kerr R and Kanyama-Phiri GY (2010) Biodiversity can support a greener revolution in Africa. Proceedings of the National Academy of Sciences 107(48), 20840-20845. doi: 10.1073/ pnas.1007199107.

Sutcliffe C, Dougill AJ and Quinn CH (2016) Evidence and perceptions of rainfall change in Malawi: do maize cultivar choices enhance climate change adaptation in sub-Saharan Africa? Regional Environmental Change 16(4), $1215-1224$. 
Taylor M (2015) The Political Ecology of Climate Change Adaptation: Livelihoods, Agrarian Change and the Conflicts of Development. London, UK and New York, NY: Routledge.

Underwood C, Skinner J, Osman N and Schwandt H (2011) Structural determinants of adolescent girls' vulnerability to HIV: Views from community members in Botswana, Malawi, and Mozambique. Social Science \& Medicine 73(2), 343-350.

Von Grebmer K, Bernstein J, Waal A, Prasai N, Yin S and Yohannes Y (2015) The 2015 Global Hunger Index: Armed Conflicts and the Challenge of Hunger. Washington, DC: International Food Policy Research Institute.
Weis AJ (2007) The Global Food Economy: The Battle for the Future of Farming. London, UK: Zed Books.

World Bank (2017) By Country Data, Malawi. Available at http://data.worldbank.org/country/malawi\#cp_wdi.

World Bank and International Food Policy Research Institute (2010) Gender and Governance in Rural Services: Insights from India, Ghana, and Ethiopia. Washington, DC: World Bank.

Zulu LC (2010) The forbidden fuel: charcoal, urban woodfuel demand and supply dynamics, community forest management and woodfuel policy in Malawi. Energy Policy 38(7), 3717-3730. 